\title{
THE CONCEPTUAL CONTENT OF STATE BUDGET PROCESS IN ECONOMIC THEORY
}

\author{
Ērika ŽUBULE 1 , Anita PUZULE ${ }^{2}$ \\ ${ }^{1}$ Dr.oec., associate professor at the Faculty of Economics and Management, \\ Rezekne Higher Education Institution, Rezekne, Latvia, \\ e-mail: erika@ru.lv, phone: +37126430306, \\ ${ }^{2}$ Mg.oec., lecturer at the Faculty of Economics and Management, \\ Rezekne Higher Education Institution, Rezekne, Latvia \\ e-mail: anitapuzule@inbox.lv, phone: +371 26413185
}

\begin{abstract}
Evaluating the role of the budget in economy we may declare that the budget process should favour the social economic development of the state. The aim of the research is to explore and evaluate theoretical aspects of the state budget process as a component of the state financial policy and to work out proposals for improvement of the state budget process, based on the theoretical and empirical findings. The main objectives of the research were to study the foreign economic scientific literature on the state budget process in the context of theoretical aspects, to study the impact of the state budget process on the financial policy and to work out proposals for the perfection of state budget process. Generally accepted research methods of economic analysis were used: the qualitative - studying the special literature, scientific publications, morphologic comparison, the logically constructive method, the method of synthesis.

As there are different views on the significance of the state budget process in the organization of state finances, the authors have specified the definition of the concept of the state budget process in the context of economics. It will ensure a unified understanding of the budget process as an important mechanism of state finance management. Therefore, a more profound theoretical research study on the state budget process is important.
\end{abstract}

Keywords: budget process, government finance, state budget, state financial policy, state finance management.

JEL Code: $H 50, H 60, E 66$.

\section{Introduction}

Since the middle of the $20^{\text {th }}$ century the regulating role of the government in the economy has increased and made the concept of the state finance more topical. Thus, the state budget concept and activities related to its implementation, which are in general defined as the budget process, has become the object of political discussions. Therefore, it is essential to study the theoretical base of the concept of budget process. It is determined by several aspects but the most important is the existing understanding and interpretation of the concept in economics, which reflects different conceptions related to the state budget and its process.

As there are different views on the significance of the state budget process in organization of state finances, it is necessary to specify the 
definition of the concept of state budget process in the context of economics. It will ensure a unified understanding of the budget process as an important mechanism of state finance management. Therefore, a more profound theoretical research study on the state budget process is important.

In research, attention is mainly focused on conceptual principles of the state budget process in the theoretical context. There is a discussion about the concept "state budget process", understanding of its content, defining the main aim of the budget process, specifying tasks and evaluating possibilities for practical execution of the budget process.

The aim of the research is to explore and evaluate theoretical aspects of the state budget process as a component of the state financial policy and to work out proposals for the improvement of the state budget process, based on the theoretical and empirical findings.

In order to achieve the aim of the research, the following objectives of the research were put forward:

1. To study the foreign economic scientific literature on the state budget process in the context of theoretical aspects (definition, aim and tasks of the budget process).

2. To study the impact of the state budget process on the financial policy.

3. To develop out proposals for improvement of the state budget process.

Novelty of the research is a perfected and formulated definition of "state budget process".

The authors put forward the following hypothesis - a specified definition of the state budget process and its consequent practical usage gives a possibility to improve the execution of the procedures of the state budget process.

Generally accepted research methods of economic analysis were used: qualitative - studying the special literature, scientific publications, morphologic comparison, the logically constructive method, the method of synthesis.

The informative and methodological basis of the research consists of the scientific theoretical literature, foreign researchers' works and publications on the corresponding topic, encyclopaedic stocks and methodological literature.

\section{The argumentation of research on the state budget process}

The government's implemented policy affects development of each country regarding the economic and social aspects. One of the main components is fiscal or budget policy. Traditionally, it is defined as 
necessary revenue and expenditure formation policy ensuring the government's performance. However, in the economic interpretation, it is an economic regulation system by the instrumentality of taxes and government expenditure. It is closely related to the role of the state in the public income redistribution, determining the proportion of the state budget in the gross domestic product, defining the objectives for the overall tax burden, budgetary expenditure, allowable deficit, government debt level and structure.

Based on the assumption that fiscal policy is the use of the state budget with the aim to facilitate economic development and to ensure effective implementation of the financial policy, the emphasis is put on importance of the budget developed by the government and approved by the legislative power in the development of socio-economic processes.

Consequently, it is important to understand the procedures related to the state budget formation because, in general, it determines the formation mechanism of the amount of funds required by the government. All of this is marked by the concept "budget process", understood as activities of the regulatory authorities in compliance with the legislative procedure in the development, consideration, adoption and execution, control and drafting of a report on the execution of a budget being the main plan in relation to public finance.

It is essential to comprehend the state budget process in the public finance context, as it is:

- a government's policy implementation process whereby the instrumentality of the budget, the funds for the government's planned activities are ensured; the choice is made, first of all indicating the tax burden concerning tax types and categories of taxpayers, secondly, classifying the government's functions by putting forward the prior ones;

- a decision-making process resulting from political debates in regard with the formation and allocation of financial resources of the government, which in its turn is related to the identification of priorities and the choice of the necessary expenditure;

- a process of formation and strengthening of subjective viewpoints that affect the state budget policy, consequently the public welfare in general.

Accordingly, speaking about the budget process, not only the public finance but also political aspects are significant, an essential element of the budget process has become the behaviour of specific people and groups in the fiscal decision-making that usually leads to unreasoned, irrational actions in the public finance management. As a result of the 
unreasonable fiscal policy in the sphere of regulation of the state finances there is a necessity to establish a new budget policy, which would be related to cardinal changes in the budget process, new approaches and understanding of composition of the state finances.

The most important problem that was put forward is the problem of stabilization of the state finances; its main solution is focused on the reduction of the state budget expenses. However, the reduction of the state budget expenses is still happening mechanically, without economic evaluation of the government's functions, their performance in work of the involved institutions.

Possibilities for reduction of the government's expenses are also accentuated already in the process of the budget planning, increasing the responsibility of users of the budget finances in it (Stewart, 2009). It is particularly urgent in the situation when there is a period of decline or crisis in the economy, and the collection of necessary revenues for the budget is problematic, which defines the immediate need in activities of fiscal consolidation, which are important at the moment for budget development of European countries. It could be concluded that now there is a necessity for more effective regulation of public finance, which is possible by evaluation of the socio-economic meaning of state budget.

\section{Economic interpretation of state budget process}

In foreign economic literature, budget has been the main object of investigation in the financial sphere. It determined the fact that mainly problematic issues of the state revenue and expenditure have been investigated. In the 1980s, when the state budgets increased, the budget deficit grew, research studies on the procedures of budget-making, their influencing factors and involved participants were actualized.

The conceptual investigation on the concept of state budget process within the public finance context is represented by different directions of economic research studies.

It is necessary to stress that the first person who pointed out the budget process as a set of political activities, was a society researcher from the USA - A.Wildavsky. Specific research studies of the aspects of the budget process were done by R.T.Meyer, D.Nice, A.Jennifer, when discussing the principal theoretical issues of the given concept, but I.Rubin contributed to the investigation of the budget process by proving the fact that it is not a static but dynamic process and it is influenced by a range of various factors.

In the field of ensuring the efficiency of state expenditure management, significant research studies were done by J.E.Stiglitz, A.Premchand, justifying the importance of qualitative and quantitative 
indicators in formation of the government's expenses. Investigation of the institutional conditions of the state budget making was done by American economist W.A.Niskanen.

Issues of budget consolidation in the field of improvement of the state financing regulation were investigated by J.Von Hagen, A.H.Hallet, R.Strauch, C.Mulas-Granados.

Issues concerning the budget process were also highlighted by the following representatives of Russian academic schools: L. Pavlov (Л.Павлов), S. Galyckaya (С.Галиџкая), A. Babich (А.Бабич), L. Drobozina (Л.Дробозина), J. Konstantinova (Ю.Константинова), M. Romanovskiy (М.Романовский), B.Sabanti (Б.Сабанти) et al.

Irrespective of research studies concerning the budget process made by the authors mentioned above, it can be asserted that there still are a number of unsolved problems both within the theoretical interpretation of budget process and the practical context of its implementation, especially when taking into consideration the national, economic and political features of each country.

Not taking into consideration the meaning of state budget, an important role is attributed to activities of national institutions, ensuring development, discussing, ratification and realization of the budget as a state financial plan. In economic literature, the activities which follow each other are called the budget process, to which a significant attention is attributed within the research studies concerning the role of state finances during implementation of state socio-economic policy. However, it should be emphasized that when discussing the budget process, different authors have different opinions and definitions of the term itself. Therefore it could be asserted that the concept "state budget process" is not unequivocally defined.

Economist, professor of Harvard University, Jeffrey D. Sachs declares that government is not ruled by one person or one political party, therefore the fiscal policy is the set of activities of the decision-making agencies, for instance, the central government, regional governments, big national companies. Therefore, the theories, stressing the necessity for rational fiscal policy, should take into consideration the fact that the fiscal policy in general is a result of complicated political process. Therefore it is related both to the institutional and political circumstances in which the government has to make its decisions (Sakss, 2002).

USA economist Ronald Fisher, when studying public finance, uses the term "Government Budget Process". R.Fisher stresses the following main aspects (Fisher, 1996):

Taking into consideration the fact that budget is a plan by which government envisages to reach its targets for pubic influence and 
improvement, then the process prescribing the budget, firstly is impacted by the economic situation;

Duration of the state budget process and its characteristic partial mixing with government activities is usually connected with problems in forecasting economic processes;

During the process of state budget there are high chances to enforce some constraints.

R.Fisher updates the fact that the main meaning of activities related to a budget is the measures performed by the government. Thus the role of subjective factor during the budget process is activated.

Significant research studies on processes of state budget are performed by Irene S. Rubin. She uses this term to denote both the Politics of Public Budgeting, and Budgetary Decision Making, as well as she uses the term Budget Process (Rubin, 1997). She considers that due to different descriptions of state budget process it can be understood as a report on data, composed concerning a particular period of time, therefore a budget could be understood as a technical event. However, I.Rubine emphasizes that the state budget process, firstly, is the flow of adequate decisions, and it is a political process, since it creates the budget power, which in its turn ensures all the process participants have stronger positions in comparison with others. It is asserted that competition is going on both between individuals and commissions or committees in legislation and between Legislative Power and Executive Power itself. In this aspect we could agree with Joseph White's, since he thinks that competitiveness between participants involved in the budget process is prescribed by different motivations (Rubin, 2008).

Summarizing the opinions reflected within research studies on the state budget process, there could be posed the following features being characteristic to the budget process, which influences the activities determining state budget differently (Figure 1).

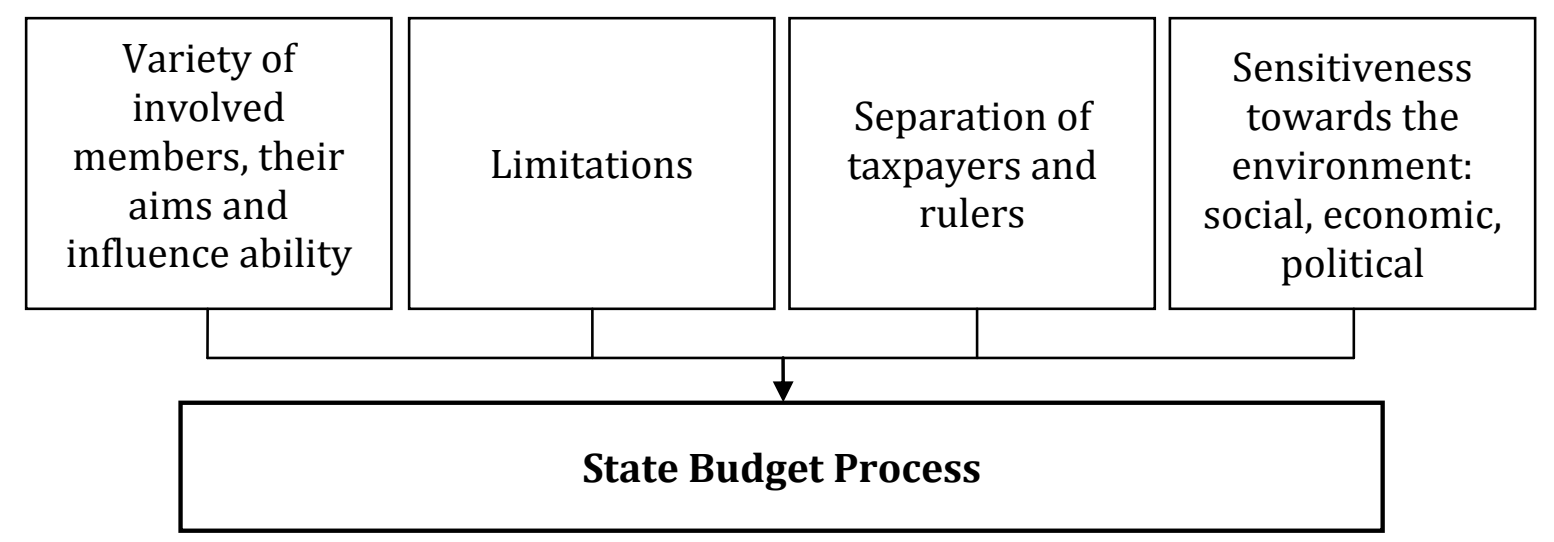

Fig.1 Main features of the State Budget Process

(Rubin, 1997; Nice, 2002; Mikesell, 2006) 
It can be concluded that for the research study on the state budget process, the following aspects should be taken into consideration:

Variety of its participants, their aims and skills of influence. This characteristic feature of budget, stressed by I.Rubin, is also emphasized by D.Nice in his research studies; he points that the state budget process involves different participants who have various opportunities to influence the course of particular process. I.Rubin considers the Executive Power and the Legislative Power as main representatives of budget process, which have different goals; it is also stressed that citizens traditionally have a smaller impact on the process. However, D.Nice has a more detailed opinion within the context of participants involved in the budget process. The mentioned economist divides the participants of state budget process into formal ones (President, Prime Minister, representatives of decision-making and Executive Power, representatives of local powers, managers of institutions) and informal ones, id est, different interest groups, for instance, retirement associations, trade unions, as well as political parties and mass media (Nice, 2002). So, there is emphasized significance of possible influence of public representatives, and for the comprehension of the state budget process concept it is necessary to accept the difference in its participants, their goals and influence abilities as the precondition for the changeability and variability of budget process.

Separation of payers and decision-makers due to the fact that during the budget process, public thoughts can be taken into account or ignored. In this context, the level of publicity within all activities related to the state budget is essential, since a budget shows how public money is collected and how effectively it is put into use. We could agree with I.Rubin's that the level of agreement between decision-makers and society is prescribed by tolerance, while conflicting and competing during the budget process (Rubin, 1997).

Limitations, because the state budget always has limits for satisfying of all needs; thus during the budget process decisions are made regarding priorities for ensuring necessary financial means and their disposal. D.Nice considers that the necessity for fiscal limitations is connected with control measures in the budget process (Nice, 2002).

Sensitivity towards the environment, which means that the state budget process is not only influenced by its participants' efforts, but there should also be taken into consideration the changes in social, economic and political environments, influencing both the income and expenditures. This opinion is supported also by J.White in his discussions about the budget process, where he emphasizes that "nothing can be more society-sensitive" (Rubin, 2008). 
The authors agree with the affirmation that the state budget process as a research object is universal and very controversial, as it is influenced by many factors and a broad variety of interpretation. The state budget process has been examined from the economic, public choice and public administration point of view, as well as in aspects of political science and political anthropology (Rubin, 2008).

It could be asserted that for the study of problems related to the state budget process, the following assumptions should be taken into account:

- The sphere of budget process activities is very dynamic and open for different opinions, therefore the research studies should emphasize the sensitivity of dynamics, while modifying theories;

- The budget process is influenced by its formation size, id est, by the fact whether it is predominated by Executive or Legislative Power, whether it is a budget of programmes, positions or institutions. Budget formation procedures influence not only the representation level of members of different budget processes, but also the provision of results and greater or smaller transparency of budget process;

- The budget process is promoted not only by particular rules, but also by a range of different norms and standards, prescribing the principles and guidelines of fiscal activity;

- The budget process differs in democratic and authoritarian countries; therefore society more or less democratically relies on transparency and responsibility in the budget process, as well as the government's sympathy towards public priorities.

We should agree with the opinion that the state budget process is partially technical. However, its politicization should be emphasized, because each political power is interested in gaining higher budgetary authority by the help of which the members of budget process could achieve their political goals (Rubin, 1997; Nice, 2002). The dependence of budget-related activities on political powers is substantiated also by Harvard professor of economics Kenneth Rogoff. He suggested term „political budgetary cycle". However, he considers that irrespective of the political budgetary cycles as a negative thing, they can influence the welfare of a country in a way, because thus society receives information about administrative competences of politicians. It is emphasized that especially in the year of elections, the budget-related activities are distorted, thus negatively influencing the national fiscal policy (Rogoff, 2003). 
Professor from Washington University David Nice emphasizes that the state budget process is the creation and accomplishment of government decisions concerning monetary fund-raising, allocation and disposal of these means. We should agree with the author's opinion that the given definition is quite wide and by this interpretation the budget process becomes an analogue to government policy-making. Therefore it is accentuated that the state budget process nowadays has become a set of disputable and complex activities (Nice, 2002).

Professor from Indiana University John L.Mikesell lays stress on the term "budgetary cycle" within the context of state budget process, defining it as a periodical and partially overlapping arrangement within the process of budget planning and disposal (Mikesell, 2007).

Not denying the interpretation of previous formulations, the authors consider that the terms "budget process" and "budgetary cycle" are not translatable analogues, because the word "cycle" means a totality of particular processes, which usually are repeated (Baldunčiks, 1999). We can agree with D.Nice's that the budget cycle is an implementation of stages of a particular year's budget processes. It is important to emphasize the significance of information in budget formation. Within the research studies on the state budget process, it is declared that the fiscal cycles are mutually connected by time, because the data of annual budget audit and evaluation provide significant information for the formation of the next year's budget.

It can be concluded that every budget process has its own individual cycle. It is influenced not only by the provision of administrative measures generally related to the budget formation, but also the sensitivity characteristic to the budget towards environmental changes economic, social and political.

The conceptual study of the state budget process indicates that there is still no common opinion regarding the role of budget process in the effective organization of national finance. Especially nowadays some uncertainties, controversial issues are appearing, proving the topicality of this issue. Therefore it is necessary to search for practical solutions, offering a new approach for provision of budget processes.

When performing a theoretical and methodological examination of the concept of the budget process, the authors conclude that in the economic literature there is a variety of opinions on explanations of the concept "state budget process" and actions that it consists of. Consequently, there is no united methodology for the identification of the mentioned concept. For that reason, in order to ensure a harmonized understanding, the authors believe that it is necessary to actualize the 
following two important concepts when defining the state budget process:

- $\quad$ state budget, which is defined in different ways in the economic literature, but mainly it is emphasised that it is a list of state revenues and expenditures, which is approved in a legal way; it is done for a concrete period of time with the aim to define and justify the amount of finances that is needed by the government for execution of the state duties, financing of which is defined by laws and regulations guaranteeing that within the definite period of time corresponding revenues would cover expenditure;

- process, which derives from the Latin word "processus" meaning advance (Švābe et al., 1927) Nowadays this word is defined as a set of successive actions for achievement of a definite aim, result (Bāliṇa et al., 2006).

The authors advise to define more exactly the concept "state budget process" in such an interpretation: the state budget process means successive continuous actions of institutions of the state executive power and decision-making power actions in creating and securing the budget as the main state financial plan, which are defined by the law and include - budget planning, reviewing the budget project, approval of the law on the budget, organization of budget execution, ensuring its control, as well as evaluation of the budget execution.

This interpretation of the definition of the state budget process includes significant aspects of this concept:

- main participants are representatives of the executive power and decision-making power;

- the goal is the state financial plan as the main tool for the implementation of the government's fiscal policy;

- defining fiscal activities for achievement of a specific goal;

- segmentation of budget action, their interaction.

Introducing a unified interpretation of the definition of the state budget process in the economic and legal terminology, the authors consider that the following problems will be solved:

1. The unified comprehension of the term "state budget process" will be developed, ensuring coordinated discussion about all issues within the mentioned context, especially within the definition of stages of budget process with the aim to identify the most important factors influencing it;

2. Since the state budget process includes a range of important stages, it should be stipulated within the law regulating the state budget, which in its turn is pointed towards ensuring a 
clear technical basis, preventing legal incomprehension within administrative, implementation and control fields of fiscal measures.

Therefore the conditions for effective public financial management become clearer. The main components of these conditions are reflected in Figure 2.

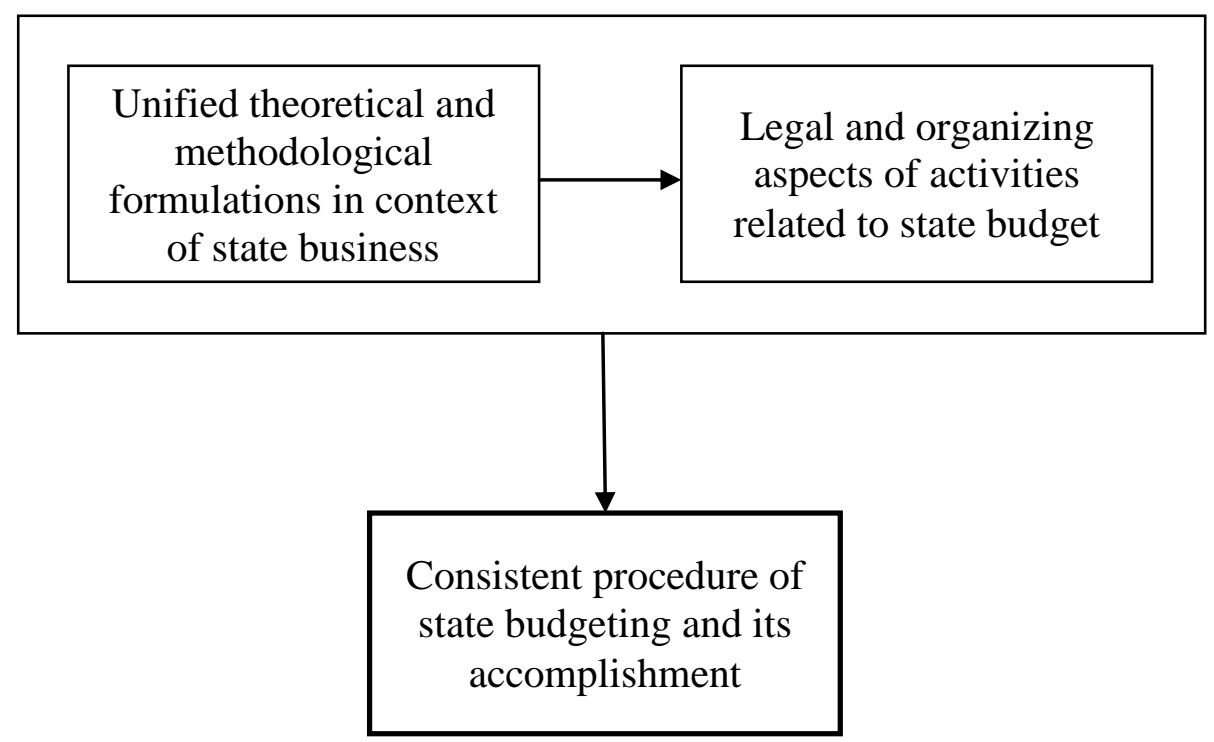

Fig.2 Main conditions for the efficiency of state financial system (compiled by the authors)

Due to the fact that theoretical opinions are traditionally based upon the evaluation of practical activity, the issue concerning accepting theoretical opinions with the aim to improve practical activity within the sphere of public finance within the context of budget process is urgent. For the theoretical study of the state budget process, it is necessary to define unequivocally its concept, determine its role, emphasizing the potential impact of included procedures and activities of participants upon the implementation of the national fiscal policy.

In this context, we cannot ignore the subjective factor, because all participants of the budget process are characterized by interest in increasing their opportunities during the formation of state budget.

During the implementation of the state budget process, the development of unified comprehension regarding public interest in general is very urgent.

\section{Conclusions and suggestions}

Based on the assumption that fiscal policy is the use of the state budget with the aim to facilitate economic development and to ensure effective implementation of the financial policy, the emphasis is put on 
the importance of the budget developed by the government and approved by the legislative power in the development of socio-economic processes.

Consequently, it is important to understand the procedures related to the state budget formation because, in general, it determines the formation mechanism of the amount of funds required by the government. All of this is marked by the concept "budget process", understood as activities of the regulatory authorities in compliance with the legislative procedure in development, consideration, adoption and execution, control and drafting of a report on the execution of a budget being the main plan in relation to public finance.

The conceptual investigation on the concept of state budget process within the public finance context is represented by different directions of economic research studies.

Irrespective of research studies concerning budget process, it can be asserted that there still are a number of unsolved problems both within the theoretical interpretation of budget process and the practical context of its implementation, especially when taking into consideration the national, economic and political features of each country.

The authors agree with the affirmation that the state budget process as a research object is universal and very controversial, as it is influenced by many factors and a broad variety of interpretation. The state budget process has been examined from the economic, public choice and public administration point of view, as well as in aspects of political science and political anthropology.

When performing a theoretical and methodological examination of the concept of the budget process, the authors conclude that in the economic literature there is a variety of opinions on explanations of the concept "state budget process" and actions that it consists of. Consequently, there is no united methodology for the identification of the mentioned concept.

The authors advise to define more exactly the concept "state budget process" in such an interpretation: the state budget process means successive continuous actions of institutions of the state executive power and decision-making power actions in creating and securing the budget as the main state financial plan, which are defined by the law and include - budget planning, reviewing the budget project, approval of the law on the budget, organization of budget execution, ensuring its control, as well as evaluation of the budget execution. 
This interpretation of the definition of the state budget process includes significant aspects of this concept:

- main participants are representatives of the executive power and decision-making power;

- the goal is the state financial plan as the main tool for the implementation of the government's fiscal policy;

- defining fiscal activities for achievement of a specific goal;

- segmentation of budget action, their interaction.

Introducing a unified interpretation of the definition of the state budget process in economic and legal terminology, the authors consider that the following problems will be solved:

- The unified comprehension of the term "state budget process" will be developed, ensuring coordinated discussion about all issues within the mentioned context, especially within the definition of stages of budget process with the aim to identify the most important factors influencing it;

- $\quad$ Since the state budget process includes a range of important stages, it should be stipulated within the law regulating the state budget, which in its turn is pointed towards ensuring a clear technical basis, preventing legal incomprehension within administrative, implementation and control fields of fiscal measures.

\section{References}

1. BALDUNČIKS, J. (red.). (1999). Svešvārdu vārdnīca. „Jumava”, 879 lpp.

2. BĀLIN,A, R., ĒDELMANE,I., GRASE, I. u.c. (2006). Latviešu valodas vārdnīca: 30000 pamatvārdu un to skaidrojumu. (Jubilejas izd.). Avots, 1211 lpp.

3. FISHER, R.C. (1996). State and Local Public Finance. (2nd ed.) Chicago, Irwin, $677 \mathrm{p}$.

4. MIKESELL, J. L. (2007). Fiscal Administration: Analysis and Applications for the Public Sector. Belmont, US, $665 \mathrm{p}$.

5. NICE, D. (2002). Public Budgeting. Wadsworth, $215 \mathrm{p}$.

6. ROGOFF, K. (2003). Debt Intolerance. Brookings Papers on Economic Activity, Vol. 1, p. 1-74.

7. RUBIN, I. S. (1997). The Politics of Public Budgeting. New Jersey, 325 p.

8. RUBIN, I.S. (ed.). (2008). Public Budgeting: Policy, Process and Politics. ASPA, $515 \mathrm{p}$.

9. STEWART, C. H. (2009). Budget Reform Politics. Cambridge Books, 254 p.

10. ŠVĀBE, Ā, BŪMANIS, A., DIŠLERS, K. (1927). Latviešu konversācijas vārdnīca divdesmit sējumos. A.Gulbja apgādībā, 2047 lpp.

11. САКС, Д. (1996). Макроэкономика. Глобалъний подход. (Перевод с английского). Москва, „Дело”, 800 с. 


\title{
VALSTS BUDŽETA PROCESA KONCEPTUĀLAIS SATURS EKONOMIKAS TEORIJĀ
}

\author{
Ërika ŽUBULE', Anita PUZULE ${ }^{2}$
}

1 Dr.oec., Rēzeknes Augstskolas,

Ekonomikas un pārvaldības fakultātes asociētā profesore, Rēzekne, Latvija

2 Mg.oec., Rēzeknes Augstskolas,

Ekonomikas un pārvaldības fakultātes lektore, Rēzekne, Latvija

\section{Kopsavilkums}

Izejot no valsts budžeta nozīmes, svarīgu lomu iegūst valsts institūciju darbības, kuras nodrošina budžeta kā valsts finanšu plāna veidošanu, apspriešanu, apstiprināšanu un izpildi. Ekonomiskajā literatūrā šīs viena otrai sekojošās darbības tiek apzīmētas ar vienu terminu - budžeta process, kuram pētījumos par valsts finanšu lomu valsts sociāli ekonomiskās politikas îstenošanā arī tiek pievērsta būtiska uzmanība.

Pētījuma mērḳis ir izpētīt un izvērtēt teorētiskos valsts budžeta procesa aspektus un, balstoties uz empīriskajiem secinājumiem, izstrādāt priekšlikumus valsts finanšu politikas pilnveidošanas kontekstā.

Pētījumā izmantotas galvenokārt kvalitatīvās pētījuma metodes: kontentanalīze - speciālās literatūras, zinātnisko publikāciju izpēte, morfologiskā salīdzināšana, logiiski konstruktīvā metode, sintēzes metode.

Autores secina, ka dažādiem autoriem, diskutējot par budžeta procesu, veidojas atšķirīgi viedokḷi un arī paša termina formulējumi. Līdz ar to var apgalvot, ka jēdziens „valsts budžeta process” nav viennozīmīgi definēts. Tiek piedāvāta unificēta valsts budžeta procesa definīcija.

Vienotas valsts budžeta procesa definīcijas interpretācijas ieviešana ekonomiskajā un juridiskajā terminologijāā ir vērsta uz šādu problēmjautājumu risināšanu:

- veidosies vienota izpratne par jēdzienu „valsts budžeta process”, kas nodrošinās saskaṇotu diskusiju par visiem jautājumiem minētajā kontekstā, it sevišksi budžeta procesa posmu definējumā ar mērķi identificēt būtiskākos tos ietekmējošos faktorus;

- $\quad$ tā kā valsts budžeta process ietver sevī virkni nozīmīgu posmu, tad tam visam jābūt atrunātam valsts budžetu reglamentējošā likumā, kas savukārt ir vērsta uz skaidras tiesiskās bāzes nodrošināšanu, novēršot trūkumus fiskālo pasākumu administratīvajā, izpildes un kontroles jomā.

Līdz ar to tiek nodrošināti izprotamāki efektīvas valsts finanšu pārvaldības nosacījumi. Tādejādi pētījuma sākumā izvirzītā hipotēze ir apstiprinājusies.

Atslēgas vārdi: budžeta process, valsts budžets, valsts finanses, valsts finanšu politika, valsts finanšu vadība. 